Litteratur

1. Wisborg T. Re: Tydeligere og bedre. Tidsskr Nor Legeforen 2016; 136: xxx.

2. Fjellhaug M. Jetfly i luftambulansetjenesten. www.legejobber.no/Nyheter/ jetfly-i-luftambulansetjenesten/ (28.6.2016).

3. Føleide A, Jacobsen L, Schanche TE. Mener ambulanseflyutskifting svekker beredskapen. www.nrk.no/finnmark/mener-ambulanseflyutskifting-svekkerberedskapen-i-finnmark-1.12969827 (28.6.2016).

\section{Re: Keisersnitt ved trisomi 13 og 18 - en verdibasert vurdering}

Vi takker Anne Mari Røsting Strand \& Siri Fuglem Berg for en tankevekkende kommentar (1) til vår artikkel (2), som handlet om keisersnitt bør tilbys ved trisomi 13 og 18, og der vi drøftet interessene til de ulike involverte partene. Vektleggingen til Strand og Berg av det relasjonelle aspektet er en velkommen utdyping av vårt punkt om foreldrenes interesser. Det er et viktig budskap fra Strand og Berg at foreldre kan vektlegge det relasjonelle og emosjonelle svært høyt. For foreldre handler det med andre ord om mer enn å avveie objektive (og svært usikre) tall knyttet til risiko og behandlingseffekt. Dette er et budskap som klinikere som skal ta behandlingsbeslutninger i samarbeid med foreldre, må ta til seg. En god dialog med foreldrene må ikke bare handle om medisinsk risiko, mulige plager og overlevelse, men også om relasjonelle og emosjonelle forhold.

Imidlertid rokker ikke dette ved prinsippet om at behandlingsbeslutningen må ta hensyn både til nytte og risiko og interessene til alle involverte. Selv om man ofte kan gi symptomlindring for å dempe plager i forbindelse med mulig livsforlengende behandlingstiltak, er det fare for at en mer aktiv behandling vil dreie fokus bort fra optimal symptomlindring og derfor påføre barnet en belastning. Hvor mye plager det er akseptabelt å påføre barnet gjennom behandling, avhenger av utsiktene til at behandlingstiltaket kan gi en langtidsoverlevelse med god livskvalitet. Imidlertid er kunnskapsgrunnlaget om nytte av ulike behandlinger hos disse barna så spinkelt at en nøye avveining av behandlingsrelaterte plager versus mulighet for overlevelse er vanskelig. Det er viktig at vektlegging av det emosjonelle og relasjonelle ikke leder til beslutninger som i ytterste konsekvens påfører barnet unødvendig lidelse. Både for foreldre med et sykt barn og for leger som behandler dette barnet, gjelder at konsekvensene av de beslutningene de fatter, også bæres av det syke barnet, som i den situasjonen vår pågående diskusjon gjelder, ikke har noen mulighet til å si verken ja eller nei.

I en nylig artikkel ble denne dissosiasjonen mellom hvem som fatter beslutningene og hvem som bærer konsekvensene, kalt «moral hazard» (3). Selv om tema for vår artikkel var avgrenset til problemstillingen om keisersnitt, ser vi at beslutningen om keisersnitt eller ikke, bare vil være den første i en lang rekke av krevende beslutninger om behandlingsvalg.

\section{Olav Fredheim}

olav.m.fredheim@ntnu.no

Thor Willy Ruud Hansen

Guttorm Haugen

Morten Magelssen

Olav Fredheim (f. 1979) er overlege og professor ved Akershus universitetssykehus og Norges teknisk-naturvitenskapelige universitet. Ingen oppgitte interessekonflikter.

Thor Willy Ruud Hansen (f.1946) er overlege og professor ved Oslo universitetssykehus og Universitetet i Oslo.

Ingen oppgitte interessekonflikter.

Guttorm Haugen (f. 1953) er overlege og professor ved Oslo universitetssykehus og Universitetet i Oslo.

Ingen oppgitte interessekonflikter.

Morten Magelssen (f. 1978) er lege med ph.d.-grad og forsker ved Universitetet i Oslo.

Ingen oppgitte interessekonflikter.

\section{Litteratur}

1. Strand AMR, Berg SF. Keisersnitt ved trisomi 13 og 18 - en verdibasert vurdering. Tidsskr Nor Legeforen 2016; 136: 1064

2. Fredheim OMS, Hansen TWR, Haugen $G$ et al. Bør man kunne tilby keisersnitt ved trisomi 13 og 18? Tidsskr Nor Legeforen 2016; 136: 630-2.

3. Brunnquell D, Michaelson CM. Moral hazard in pediatrics. Am J Bioeth 2016; 16 : 29-38.

\section{RETTELSE}

Skoliosescreening anbefales for jenter

Raphael Adobor

Tidsskr Nor Legeforen 2016; 136: 1027

I omtalen av Adobors doktoravhandling skal «juvenil idiopatisk skoliose» erstattes av «adolescent idiopatisk skoliose». Det skal altså i første avsnitt stå: Adolescent idiopatisk skoliose er den vanligste ryggskjevheten hos barn. Og i siste avsnitt: Funnene i mitt doktorarbeid har bidratt til økt kunnskap om oppdagelse, forekomst og behandling av adolescent idiopatisk skoliose.

Vi beklager feilen. Den er rettet på nett. 